\title{
Forgiveness as the Guiding Principle for Individual Rebirth and Modern Universal Renaissance
}

\author{
Tone Svetelj \\ Hellenic College, Boston College, USA
}

\begin{abstract}
In this paper, I first create new frameworks for a reflection on "human" and "humanism" in the time of globalization. As our intellectual perception of the world is becoming more universal and all-inclusive, so should also our hearts. The heart is the inner most core of being human, to become able to expand in unprecedented dimensions of human existence. In this context, I propose forgiveness as the guiding principle of expansion and inclusion, and consequently of becoming more human. If memory helps us to survive, forgetting allows us to go on living. The practice of forgetting, and consequently of reconciliation, is the distinctive and complex moment of human existence, when the human agent makes him/herself open and available to the present moment, and lives fully in the present moment. Once doing so, the present moment becomes the space in which s/he can reconcile with his/her past and shape his/her future. In the second part, I check possible impediments on our way to expansion and inclusion, as well as in our process of forgiveness and reconciliation. Patañjali, in his instructions to yogis talks about kleshas, i.e. impediments or afflictions, which are weakening our way of thinking and acting. These kleshas include ignorance, ego, attachment, aversion, and the clinging to life. I take these kleshas also as afflictions on our way to becoming more human, or as impediments in our process of forgiveness and reconciliation. Finally, I reflect on the human urge to become more human. In our time of globalization, we are challenged to look at this urge from a universal perspective. This urge, bound with an inevitable process of forgiveness and reconciliation, challenges each religion and its dogmatic teaching, and represents the evaluative criterion. The spirituality, or religion, that which promulgates and lives forgiveness and reconciliation will automatically excel because it will succeed, without losing its own identity, to integrate and include otherness of the other.
\end{abstract}

Keywords: humanism, globalization, forgiveness, reconciliation, kleshas, Patañjali

Our perception of the world, opened to the process of globalization, seems to be exposed to more universal and all-inclusive interpretation of our reality. Economy, trade, and politics increasingly transcend the state boundaries and operate internationally. Modern sciences focus less on dividing and atomizing, and more on connecting and synthesizing. Collaboration, interconnectedness, interacting, expansion, and inclusion appear to be the key principles of all modern activities. An increasingly complex interaction of personal, social, political, economic, religious, cultural, and other factors condition our daily life in the context of globalization, which offers us a myriad of new and unheard opportunities for further exploration on one side, and on the other side, affects us by its crimes, violence, and cruelty on the global level.

Tone Svetelj, Ph.D., Professor of Philosophy, Hellenic College, Boston College. 
In this world of integration and interconnectedness, one of the ancient challenges remains the recurring request to create healthy relationships with people I share my life-space, to be in touch with nature that is my primordial life-sustainer, and to take care of the innermost dimensions of my life. Restoration of healthy relationships becomes crucial, especially when we have to deal with injustice and violence, inflicted on us by others. Even though it might sound paradoxical, the best way to come away from the human evil is our ability to forgive.

The goal of this article is to introduce a narrative about forgiveness as the guiding principle toward what I call universal renaissance and universal humanism. This narrative is universal for two reasons: first, it can be applied to all individuals and nations; nobody should be excluded from offering or accepting forgiveness. Second, forgiveness is a very complex act, including human reason, emotions, feelings, and spiritual dimensions of our existence, and touching the whole existence of the individual.

When forgiveness takes place, we are able to expand toward unprecedented dimensions of human existence; forgiveness enables us to perceive ourselves and the world around us in a perspective that allows us to be reborn; to rediscover new spiritual and intellectual potential; and to grow into what we are supposed to be: more goodness, more love, more friendliness, more togetherness, as Archbishop Desmond M. Tutu states in the foreword to Forgiveness and Reconciliation (Helmick, Raymond, \& Petersen, 2002, p. 13). Through forgiveness we become more what we are supposed to be: more human.

\section{Rediscovery of Forgiveness in Modern Times}

Even though forgiveness, followed by reconciliation, presents two inevitable factors in our ongoing effort to become more human, the meaning of this term is not unanimously defined. At the beginning of the 20th century, exploration of forgiveness stayed almost in the exclusive domain of religion, spirituality, theology, and philosophy. Despite his insightful exploration of the human psyche, Sigmund Freud wrote nothing about forgiveness. Carl Jung, Karen Horney, Alfred Adler, and Viktor Frankl, the founders of the mental health sciences, paid little attention to the phenomenon of forgiveness. Such neglect of forgiveness might be due to the traditional links between forgiveness and religious belief, or to the lack of reliable data about forgiveness, or to the fact that the 20th century was the bloodiest and probably the most unforgiving century in human history, perhaps leading people to conclude that forgiveness constituted little more than a nice sentiment (McCullough, Pargament, \& Thoresen, 2000, p. 3). Only toward the end of the past century can we trace an increased interest of exploration of forgiveness in the academic sphere first, and then in medicine, psychology, sociology, politics, education, and neurobiology. Nowadays the contemporary world talks about forgiveness almost at every step: forgiveness is the cure for personal and political wrongs, the road to eternal salvation, and the secret to mental and physical well-being. David Konstan goes even further when he claims that the modern topic of forgiveness is a completely new phenomenon, essentially linked to modern understanding of the self. Forgiveness is not a simple notion, but a constellation of ethical and emotional components, including remorse and personal transformation, that together constitute an essential part of modern moral consciousness. These related ideas are absent in classical thought (Konstan, 2010, p. 10).

There is no consensus about the meaning of forgiveness; philosophers, theologians, psychologists, therapists, as well as those in non-academic circles develop various interpretations about the importance of forgiveness, which causes additional perplexity in our search for its meaning. Our analysis and reflections about forgiveness, followed by varied practices of forgiving, are meaningful attempts to describe what is 
evident. Morton suggests that instead of having one concept of forgiveness, we should talk about territories of forgiveness, which vary in different times and cultures (Morton, 2012, pp. 4-5). Worthington's explanation of forgiveness is even more detailed; he distinguishes diverse types of forgiving, covering different processes. For example, we forgive strangers in a different way than our loved ones. Our experiences and definitions of forgiveness might change over time. Forgiveness relates also to perceived level of injustice, which can additionally confuse our understanding of forgiveness. The decisive factor in various processes of forgiveness presents emotional forgiveness, which is much more than an intellectual rumination about forgiveness; it is calling for replacement of negative, unforgiving emotions with positive, other-oriented emotions (Worthington, 2006, p. 17). The Mayo Clinic defines forgiveness as "a decision to let go of resentment and thoughts of revenge. The act that hurt or offended you might always remain a part of your life, but forgiveness can lessen its grip on you and help you focus on other, more positive parts of your life. Forgiveness can even lead to feelings of understanding, empathy and compassion for the one who hurt you" (Mayo Clinic Staff). At the beginning of his book Forgiveness Is a Choice, Robert D. Enright (2001, p. 25) describes forgiveness as a process or path to freedom, where forgiving means much more than just accepting what happened, or ceasing to be angry, or being neutral toward the other, or making oneself feel good. Forgiving is an act of compassion, benevolence, and love toward the offender, even though we know that s/he does not necessarily have a right to such gifts.

This reflection does not intend to collect different definitions of forgiveness, compare them, and identify the best one among them; all of them have something important to say about forgiveness. Independent of their differences, all of them seem to be built on one core feature: when people forgive, their responses, thinking, feeling, doing toward people who have offended or injured them become more positive and less negative. This is a fact that modern psychology, therapy, medicine, neuroscience, politics, management, and pedagogy prove with their statistical experiments. Forgiveness helps victims of abuse, trauma, and bullying (Watson, Rapee, \& Todorov, 2015); predicts mortality and affects longevity (Toussaint, Owen, \& Cheadle, 2012); stabilizes blood pressure and improves cardiovascular outcomes (May, Sanchez-Gonzalez, Hawkins, Batchelor, \& Fincham, 2014); increases relationship satisfaction and decreases negative conflicts (Braithwaite, Selby, \& Fincham, 2011); affects the productivity of an organization (Fehr \& Gelfand, 2012). By summarizing different definitions of forgiveness, McCullough states that forgiveness brings an intra-individual and pro-social change toward a perceived transgressor (McCullough et al., 2000, p. 9). The change in this case relates first of all to the forgiver, who gives up anger and the desire for revenge, commits him/herself to transcend bitterness and forego vengeance, and is willing to restore a moral relation with the wrongdoer (Konstan, 2010, pp. 12-13). Even here there arises a divergence of view about what forgiveness means: some claim that we cannot forgive on our own, without recognition and responsibility on the part of the offender. Emanuel Levinas (1990, p. 19) is an extreme defender of this position when he writes: "There is no forgiveness that has not been requested by the guilty. The guilty must recognize his sin". A failure to take responsibility adds insult to injury, and undermines the possibilities of trusting that the offender will not turn around and repeats the injury (Griswold, 2007, p. 49). Those who disagree with the view that recognition from the part of the offender is a necessary condition for forgiveness argue that forgiveness is universal and independent from the wrongdoer and his/her gesture of repentance and apology.

No matter which definition of forgiveness we take, it is sufficient for our reflection to claim that forgiveness brings more positive than negative aspects to our lives. It qualitatively changes the life of the 
forgiver, and hopefully that of the wrongdoer as well. Forgiveness transforms the innermost core of being human so that it is able to expand in unprecedented dimensions of human existence, and to perceive one's own life differently, free from past burdens, grievances, blame, and wounds. In short, forgiveness makes us more what we hope to be: more human. If this is the case, then forgiveness has remained a relatively little explored potential for a more harmonious process of globalization. If there are so many positive aspects of forgiveness, why is it, then, so difficult to forgive, or at least embrace the process of forgiveness? Despite the growing interest in the study of forgiveness, this aspect lacks necessary attention.

\section{Patañjali's Kleshas or Afflictions of Mind on the Way to Forgiveness}

No matter how we describe it, the process of forgiveness always starts at the same point: with the forgiver. Once I make the decision that I am willing, strong enough, and mature enough to embrace the whole process, forgiveness can take place. This might sound like a simple step, but it is not. Those who have a personal experience of forgiving or being forgiven are aware of the complexity of the act. What makes this step so difficult to understand and undertake?

As mentioned previously, there are different forms and levels of forgiveness: from forgiveness of myself, to forgiveness of somebody else, a group of people, and an entire nation. Forgiveness of myself remains the most difficult type of forgiveness because it presupposes a deep insight into my own life, way of thinking, emotions, motivations, past experiences, wishes, inclinations, family, social life, culture, religion, or in one word: my own ego. By ego in this case I refer to the identification with my thoughts, or to the convictions that what I think, believe, or simply hold in my mind, is necessarily true; I believe that the outside reality necessarily corresponds to my inner way of thinking and believing. Forgiveness of myself, as well as forgiveness of somebody else starts with allowing myself to believe that things can be different, which consequently means that I am able to distance myself from the present way of thinking and believing. In other words, thank to my capacity for awareness, I create an additional space around my thoughts, beliefs, and ego. This is exactly the point of the greatest struggle: how to change or create a distance from my present way of thinking which is creating whom/what I believe to be true? Forgiving myself is the hardest form of forgiveness because it presupposes the transformation of my ego, and transcendence of my self-centeredness. It is hard because I play two roles simultaneously: wrongdoer and forgiver. It is hard because the voice of self-condemnation often seems incessant. There is no escaping from myself because I know all the information. It is hard because I have to face myself in reality.

Some of Patañjali's Yoga Sutras, a collection of 196 aphorisms about Ashtanga Yoga, offer us an insightful view into how to create an additional space around the ego. Patañjali is not the author but the editor of these aphorisms, bringing clarity and unity to Indian philosophical systems prevalent at his time. ${ }^{1}$ These aphorisms are meant as preconditions for those who would like to start walking on the path of yoga because they open the yogi's mind for something bigger than him/herself. As such, these aphorisms have no direct connection with forgiveness. Nonetheless, they present a useful platform for our reflection about forgiveness, especially for how to open our mind to the reality of forgiveness.

\footnotetext{
1 There is not much historical information about Patañjali, who supposedly lived around the second century BC. Some practitioners believe that he also wrote significant medical works on Ayurveda and Sanskrit grammar; all these together made him a Renaissance man of his time.
} 
In the middle of his book, Patañjalitalks about kleshas, a term that can be translated as "obstacles," or afflictions of the human mind, or destructive and disturbing emotions hindering the yogi's practice (Sutra II.3). These kleshas are: ignorance, ego, attachment, aversion, and clinging to life. As afflictions of the human mind, they are blocking the agent from opening him/herself to a bigger reality, either to the benefits of yoga, or in our case, to forgiveness. Kleshas can be also considered as expressions of human suffering and inability to come into existence as a differentiated being. Prasada (2000, p. 91) describes kleshas as "forms of unreal cognition," preventing us from having true knowledge. In Patañjali's reflection, kleshas hold us in the endless cycle of birth, death, and rebirth, i.e., in a perpetual world of un-change. Similarly, we could say that, in the context of forgiveness, kleshas keep us in a repetitive way of thinking, feeling, and acting, conditioning our present and future. Once I learn how to deal with these obstacles, I will be able to create an additional space in my mind, and become ready for a more soothing relationship toward others and myself. These kleshas have to be studied as a bundle of afflictions, or as interchangeable troubling forces, disturbing our inner equilibrium on the intellectual, emotional, and spiritual levels. The first two kleshas, ignorance and ego, combined with pride and arrogance, condition our intellectual level of existence, which includes spiritual knowledge as well. The third and fourth kleshas, our attachments and aversions, belong to emotions and feelings, which can create complex disharmony and psychosomatic disorders. The last klesha, clinging to life, affects more our instinctive level of existence. Because of the interconnectedness, the kleshas should be studied together; for our purpose, we will analyze them one by one.

The starting and the main obstacle is avidy $\bar{a}$, which is generally translated as ignorance (Bryan, 2009, p. 177), or nonwisdom and delusion (Chapple \& Anand, 1999, p. 57), or lack of spiritual knowledge (Iyengar, 2002, p. 111). Patañjali describes it as "the breeding ground of the other kleshas, whether they are in a dormant, weak, intermittent, or fully activated state" (Sutra II.4). As such, avidyā creates the substratum for all other kleshas; once ignorance is dispelled, the other kleshas disappear (Bryant, 2009, p. 177). In the state of ignorance or distorted perception of reality, the yogi is not able to perceive the true nature, either in him/herself or in others; his/her life is full of pain and sorrows. His/her lack of spiritual knowledge entails confounding the nature of the soul, which represents the joyful, pure, and eternal, with the body, i.e., with the painful, unclean, and temporary. The yogi exchanges the impermanent for the permanent, and mistakes pain for pleasure. Due to ignorance, the yogi lives in a conventional awareness, which is the opposite of true knowledge (Sutra II, 5).

Similarly, the process of forgiveness cannot start as long as ignorance, or my incapacity to perceive others and myself in a different way, holds me in the conviction that my present perception of reality is the only and best possible one. Because of my ignorance (delusion, nonwisdom), I firmly hang onto my past experiences, certain ways of thinking, unpleasant emotions, hurt feelings; I believe that they are so strong that there is nothing behind them and that perception of my reality cannot be different. In other words, the inability to see more deeply presents in me an obstacle on my way to perceive myself differently. Knowledge, followed by a different comprehension of reality, is only the starting point of a longer process, both in the process of forgiveness, as well as in Patañjali's reflection. Patañjali was not a rationalist who believed that desired change will automatically follow our having right knowledge; a deeper comprehension of reality is only the starting point of a longer process.

The second klesha is asmitā (Sutra II, 6) usually translated as ego, egoism, or self-centeredness, which Bryant interprets as the following. Imagine a person wearing spectacles to see clearly, but due to his mental disorder, he refuses to remove them and believes that the spectacles are his very self rather than an instrument 
for better seeing. Ego entails doing something similar: it imagines that the mind and body, which are simply instruments allowing awareness to perceive the world, are the actual self (Bryant, 2009, p. 186). Iyengar defines egoism as "the identification of the seer with the instrumental power of seeing" (Iyengar, 2002, p. 114). Though there is a distinction between the seer and the seen, in ego they merge in oneness, which is due to asmitā. This affliction, consequently, prevents me to be in touch with my true self; instead of identifying myself with the true self, i.e., the subject of experience, I identify with the apparent self, i.e. the object of experience.

The person who is not able to forgive identifies him/herself with his/her experiences of being hurt by the wrongdoer. A mixture of emotions, feelings, thoughts, and actions can condition somebody's experience in such a way that s/he identifies completely with that experience; his/her experience becomes him/herself. When this happens, his/her ego prevents him/her from forgiving him/herself or the wrongdoer, and letting go of his/her wounds.

Inability to let go of anything is the expression of the third klesha, rāga, translated as attachment, desire, and emotional bondage to any source of pleasure (Sutra II, 7). As any attachment to pleasures prevents me from encountering something deeper in myself, so attachments to my ideas, judgments, convictions, and prejudices blocks me from seeing the reality from a different perceptive. Through these attachments, I hope to experience in the present or in the future a certain pleasure from my past, which I keep alive in my memory. Therefore, the key ingredient of this process becomes memory (Bryant, 2009, p. 189). Every form of attachment is a limitation to my freedom and a hindrance on my way to a deeper level of self-realization in the present and the future. Attachments are expressions of my desire for security. By removing attachments in me, I create in myself new dimensions of human flourishing, and become freer.

In view of forgiveness, attachments to my ideas, past experiences, emotions, feelings, and especially the inner wounds, present a crucial step in the process of forgivingness. A continuous remembering of past events or an ongoing recurring of certain narratives might be expressions of my attachments to the "pleasures" of being wounded, right, or better than other my wrongdoer. This creates in me a sense of security, satisfaction, and self-realization, even though it does not allow me to grow in freedom and new self-confidence. In this perspective, the process of cleaning our memories becomes an inevitable step for creation of additional space around the ego.

The attachment to pleasures, past experiences, unfulfilled desires, or unhappiness in the present triggers recurring experiences of pain, sorrow, aversion, feeling of resistance, anger, frustration, and misery. In an extreme case, because of his/her strong attachments, one can come to hate him/herself, his/her family, others, and the surroundings. All this together defines the meaning of the fourth klesha, called dvesah, or aversion (Bryant, 2009, p. 190). Iyengar states that pleasurable experiences from the past generate greed and lust, which strengthens attachment and stimulate a greater craving. One becomes absorbed by the pursuit of pleasure and addicted to gratification. At the same time, pain, sorrow, and misery trigger a chain of hate or aversion, leading to sorrow (Iyengar, 2002, p. 116). Dvesah prevents me from stepping out of the comfort zone of my ego and from my facing the sensations of like/dislike in me.

By facing dvesah in the process of forgiveness, I learn how to face my attachments on emotions, ideas, past experiences, which are conditioning me in my way of thinking, and preventing me from different acting. When I resist or resent something in the present, when I struggle to forgive now, it is because I remember how these things caused in me pain in the past. 
The last klesha, abhinivesha, translates as clinging to life or fear of death. This attachment is so strong that even wise and educated people cannot easily remain indifferent to the love of life and the urge for self-perpetuation, Patañjali states in Sutra II, 9: "[The tendency of] clinging to life affects even the wise; it is an inherent tendency." Carrere interprets abhinivesha in terms of the human desire to hold onto life, to seek security in the continuity and stability of what must be forever in flux (Carrera, 2006, p. 114). Mehta describes this klesha as the human desire "to hold life in the framework which the sense of I-ness has created... in the network of the mind" (Mehta, 1990, p. 115). Independently from our interpretation, abhinivesha points to the inherent human desire to live, which can be translated also as fear of death. This fear is based on our memories of losing something, not being able to completely control one's own life, and finally dying.

By not being attached to my life, i.e., my ideas, emotions, past experiences, and convictions that I am the master of my life, even the fear of losing my own identity diminishes. Once detached from clinging to my life, comprehension of my identity changes from something static to something that is in a continuous process of evolution and growth.

The process of elimination of kleshas softens and opens the yogi's mind for a yet-unknown reality of yoga; similarly, the process of elimination of afflictions in my mind prepares me for forgiveness. These kleshas should not be considered as a moral act; nonetheless, they are essential prerequisites of every moral action.

\section{No Future Without Forgiveness}

Forgiveness Is a Choice is an inspiring statement of Robert D. Enright's (2001) book with the same title. Forgiveness, like happiness and compassion, is not something that will take place by itself, automatically, without my decision to be actively involved in the process. Forgiveness takes place when I decide to forgive, i.e., when I feel courageous enough to face the wounded parts of my existence and decide that my life should not be limited by the prison of those wounds. Forgiveness is much more than a single act; it is a process in which I deal with my past life, and by doing this, I experience something that changes the course of my life in the present and shapes my future. To a certain extent, we could say that forgiveness is a lifelong process, affecting each period of our lives, as illustrated in the biblical story of Jacob and Esau. These two brothers were already in a dispute before birth, as if nature had imposed their destiny to be an ongoing rivalry. Despite Jacob's ongoing struggle with Esau and his in-laws, Jacob reconciled with his God, himself, and his brother; his forgiveness and reconciliation became for him a redemptive act, leading him to the fullness of life and healing (Gerjolj, 2012, p. 50).

If forgiveness is a matter of choice, then this choice is closely bound with our decision about what to do with our past unpleasant events and memories, which are playing a crucial role in our present life. Patañjali's kleshas remind us that afflictions of the mind are narrowly conditioned by memories of past events, which we keep alive in the present. The way we deal with our memories affects our present and future existence.

\footnotetext{
"In forgiving, people are not being asked to forget. On the contrary, it is important to remember, so that we should not let such atrocities happen again. Forgiveness does not mean condoning what has been done. It means taking what happened seriously and not minimizing it; drawing out the sting in the memory that threatens us to poison our entire existence". (Tutu, 1999, p. 271)
}

This is one of the final thoughts from No Future without Forgiveness, Archbishop Desmond Tutu's reflection about the forgiveness process in South Africa. A true forgiveness accepts what happened in the past, 
all of the past, without nursing grudges, blame, and grievances, anchored in our past. When we relinquish them in the present time, we make possible our future. Through forgiveness, we are willing to accept the uncertainty of the future, which is out of our control; nonetheless, our decisions in the present time affect our future. Hence true forgiveness is based on an all-inclusive view, in which the past, present, and future meet. If and how they will meet depends on our ability to deal with the kleshas in our mind and on our ability to renounce ourselves in our ego, conditioned by memories of unpleasant past events, grudges, and blame. Once they stop marking our present, we allow ourselves to be reborn, able to create new relationships with ourselves and the other(s), and to live a better life.

Let us take the process of globalization as an unprecedented opportunity for being in touch with others on the global level. This opportunity is conditioned by many factors: our past experiences and relationships with others, different kinds of power, our beliefs, and our present (dis)ability to create good relationships with others. Globalization, with its growth of interconnectedness and interdependency, challenges also my present identity and sovereignty. As my past events condition who I am in the present, so my present defines who I will be in the future. This is true also for every individual, community, society, state, nation, religion, and so on.

Every relationship in the present automatically opens the space for self-evaluation and redefinition of myself. If I want to establish and keep a relationship with the other, the presence of the other will indirectly bring me to a re-evaluation of my own sovereignty and redefinition of my identity. Such a process can also be considered as forgiveness, even though it surpasses the context of disagreement. Forgiveness, as the renunciation of my sovereignty and redefinition of my identity, is an expression of my willingness to accept another as a partner in the relationship because I do not want to be alone. Once I accept somebody as a partner, Levinas writes in his Totalité et Infini, I also become obliged and responsible for him/her because I cannot pretend that I have not met him/her. This responsibility explains why forgiveness is not an easy step; it is much easier to remain alone and without any obligations. By being alone, however, I remain incomplete, imperfect, and unable to achieve my own completeness. Only when I accept my own imperfection, and acknowledge the imperfection of others, I open myself to life in fullness (Osredkar, 2012, pp. 190-191).

Referring to Levinas' reflection, ego can be taken as an illusion of perfection. My attachment to my ego makes it difficult to accept my own imperfection, incompleteness, and weaknesses; the presence of others automatically challenges these attachments, or holds me in the conviction that their presence is an unnecessary burden. Recognition and acceptance of my attachment to the illusion of being perfect puts me on the path toward freedom and fulfillment, which goes through the other. Forgiveness in this case reminds me that I am incomplete, imperfect, and weak; as such, I need to be with others. Recognition of being incomplete and in need of the other cannot be described as a single act, but as an ongoing event, continuously redefining the subjects in relationship. Accordingly, even forgiveness becomes an ongoing event, taking place in continuous search of a new reality, both in me and in the others. By forgiving, i.e., being free from my attachments, I allow the others and myself to be different, changed, and reborn in the present moment, and open to a better future.

In the context of globalization, forgiveness becomes more than a moral imperative or theological dictum; it is the only means, given our humanness and imperfections, to overcome hate and condemnation, and to proceed with the business of growing and loving (Coleman, 1999). So the process of globalization becomes the playground for our becoming more human, which is exactly what we are supposed to become. The past tensions and conflicts should not present unbridgeable obstacles. Jankélévitch's reflection can be very inspiring in this regard. "...forgiveness extends to infinity...there is an inexcusable, but there is not an unforgivable. 
Forgiveness is there to forgive precisely what no excuse would know how to excuse... On this way to a better future, nothing should result as impossible" (Jankélévitch, 2005, p. 156).

\section{Conclusion: Religious vs. Secular Accounts About Forgiveness}

We started our reflection with an urge to become more human, this time from a universal perspective. This urge, bound with an inevitable process of forgiveness and reconciliation, was a challenging task in the past, and has remained a challenge for each individual, community, nation, and religion with its dogmatic teaching in the present. The urge to become more human, together with the ability to forgive, introduces two evaluative criteria of success. Religions with their spiritual and dogmatic teaching are in a special way exposed to this urge and challenge. In the context of globalization, spirituality and religion not only promulgates but also lives forgiveness and reconciliation will spontaneously excel because it will succeed-without losing its own identity - to integrate and include the otherness of the other. As such, it will contribute something more meaningful to the world of globalization, immersed in conflicts and tension. Religion, which will be able to forgive the past wrongdoing, and consequently to integrate and to include the otherness of the other, especially the wrongdoers, will excel because it will indicate an alternative way to the still fighting and opposing sides. Religion that promulgates reconciliation and forgiveness will be opening new dimensions of dialogue on the universal level, and at the same time, indicate new horizons of becoming more human.

If, in past centuries, forgiveness was in the domain of religion and spirituality, especially of Christianity in the case of Western societies, this is not the case anymore. As previously discussed, in modern times the phenomenon of forgiveness slipped out of the religious domain and became the object of non-religious studies, from psychology to economics and political science. An essential difference, however, remains between religious accounts of forgiveness and what modern science understands by forgiveness. The latter comprehension of forgiveness does not refer to any transcending entity, for example God in Christianity, as the guarantor of forgiveness and absolution; the forgiver and wrongdoer are not invited to return to the Lord, as is the case in the Christian account; when forgiveness seems impossible for man, it is still possible for God.

The modern conception of forgiveness is not based on God, but on the moral autonomy of each individual who is in continuous search of moral transformation. David Konstan argues that the modern comprehension of forgiveness has its roots in the ethical thinking of Kant, who treats human beings as ends in themselves, able with their rationality to define what the good is. Consequently, forgiveness is not directed to God or a religious entity anymore, but to the fellow humans whom one has wronged. So we have a secular notion of interpersonal forgiveness, separated from a religious background. In spite of this separation, the agent of forgiveness still believes in new horizons and visions, which will take place through his/her moral transformation and change of his/her nature (Konstan, 2010, pp. 165-166).

While a religious account about forgiveness rooted in Christian tradition might seem unacceptable for a secular society and non-Christian world, the secular account surpasses boundaries of all religious accounts and can be understood, and hopefully accepted, by every reasonable person of good will. In agreement with Charles Taylor's reflection on modern times, here we have another example of how the secular world adopts certain principles and narratives originally grounded in religion, and reshapes their functionality by granting them an old-new meaning. While the Christian account argues that forgiveness is important because it brings us closer to fullness of life, salvation, life with God, the secular account talks about forgiveness as something essential for a life of quality, either as individual or as community, brings us healing and inner peace, reduces depression, 
allows us greater self-acceptance, and creates more meaningful relationships. While the religious account is grounded in the Bible and tradition, the secular account finds its support in scientifically objective research and investigation. While the first one teaches that forgiveness is crucial for salvation of our souls, the second one regards forgiveness as an essential feature for the general well-being of the body, psyche, emotions, intellect, productivity, longevity, and the like. With the modern account, the necessity of forgiveness becomes something universal, transcending religious convictions, and deeply rooted inhuman nature. These two accounts should not be seen as two opposing accounts; they present two slightly different narratives about human ability to transcend oneself, and consequently to become more human. While the secular account seems to have a larger reach with its emphases on the utilitarian benefits of forgiveness, the religious account goes deeper and enables us to transform the darkest dimensions of human existence.

My willingness to forgive as well as my incapacity to embrace forgiveness is transforming my present life and affecting the future, regardless of what account of forgiveness I follow. Both accounts are based on the belief that forgiveness is possible and beneficial. Those who claim that forgiveness is not possible lose hope in humankind. Those who embrace forgiveness as a lifestyle are in the process of being reborn and bring new life to the present. Forgiveness is not an end in itself; it is only the beginning of something in the present moment with unknown dimensions in the future.

\section{References}

Braithwaite, S. R., Selby, E. A., \& Fincham, F. D. (2011). Forgiveness and relationship satisfaction: mediating mechanisms. Journal of Family Psychology, 25(4), 551-559.

Bryant, E. (2009). The yoga sutras of patañjali. New York: North Point Press.

Carrera, J. (2006). Inside the yoga sutras. Virgina: Integral Yoga Publications.

Chapple, C., \& Anand, V. (1999). The Yoga Sutras of patañjali. Delhi-India: Sri Satguru Publications.

Coleman, P. (1999). Quoted in Christian Science Monitor. Retrieved from http://www.csmonitor.com/1999/0128/p13s1.html

Enright, D. R. (2001). Forgiveness is a choice. Washington, DC: American Psychological Association, Life Tools.

Fehr, R., \& Gelfand, M. J. (2012). The forgiving organization: A multilevel model of forgiveness at work. Academy of Management Review, 37(4), 664-688.

Gerjolj, S. (2012). Education for reconciliation on the example of conflict between Esua and Jacob. In J. Juhant \& B. Žalec (Eds.), Reconciliation: The way of healing and growth. Berlin: LIT Verlag.

Griswold, C. (2007). Forgiveness: A philosophical exploration. Cambridge: Cambridge University Press.

Helmick, G., Raymond, S. J., \& Petersen, R. L. (2002). Forgiveness and reconciliation: Religion, public policy \& conflict transformation. Philadelphia, London: Templeton Foundation Press.

Iyengar, B. K. S. (2002). Light on the yoga sutras of patañjali. London: Thorsons.

Jankélévitch, V. (2005). Forgiveness (A. Kelley, Trans.). Chicago and London: The University of Chicago Press.

Konstan, D. (2010). Before forgiveness: The origins of a moral idea. Cambridge, New York: Cambridge University Press.

Levinas, E. (1990). Nine talmudic readings (A. Aronowicz, Trans.). Bloomington: Indiana University Press.

May, R. W., Sanchez-Gonzalez, M. A., Hawkins, K. A., Batchelor, W. B., \& Fincham, F. D. (2014). Effect of anger and trait forgiveness on cardiovascular risk in young adult females. The American Journal of Cardiology, 114(1), 47-52.

Mayo Clinic Staff. (n.d.). Forgiveness: Letting go of grudges and bitterness. Retrieved from http://www.mayoclinic.org/healthy-lifestyle/adult-health/in-depth/forgiveness/art-20047692

McCullough, E. M., Pargament, K. I., \& Thoresen, C. E. (2000). Forgiveness: Theory, research, and practice. New York, London: The Guilford Press.

Mehta, R. (1990). Yoga: The art of integration. Wheaton, Illinois: Theosophical Pub House.

Morton, A. (2012). What is forgiveness? In L. C. Griswold \& D. Konstan (Eds.), Ancient forgiveness, classical, judaic, and christian. Cambridge, New York: Cambridge University Press.

Osredkar, M. J. (2012). Forgiveness allows a new creation? In J. Juhant \& B. Žalec (Eds). Reconciliation: The way of healing and growth. Berlin: LIT Verlag. 
Prasada, R. (Trans, Ed.). (2000). Patañjali's yoga sutras. New Delhi: Munshiram Manoharlal Publishers Pvt.

Toussaint, L., Owen, A. D., \& Cheadle, A. (2012). Forgive to live: forgiveness, health, and longevity. Journal of Behavioral Medicine, 35(4), 375-386.

Tutu, D. M. (1999). No future without forgiveness. New York: Doubleday.

Watson, H., Rapee, R., \& Todorov, N. (2015). Forgiveness reduces anger in a school bullying context. Journal of Interpersonal Violence, 32(11), 1-16.

Worthington, L. E. J. (2006). Forgiveness and reconciliation, theory and application. New York, London: Routledge, Taylor \& Francis Group. 